\title{
Cheese factory wastewater treatment by anaerobic semicontinuous digestion
}

\author{
J. Lebrato ${ }^{1}$, J.L. Pérez Rodríguez ${ }^{1}$, C. Maqueda ${ }^{2}$ and E. Morillo ${ }^{2}$ \\ ${ }^{1}$ Instituto de Ciencia de Materiales, C.S.I.C., Aptdo. 1052, 41080 Sevilla (Spain) \\ ${ }^{2}$ Instituto de Recursos Naturales y Agrobiología, C.S.I.C., Aptdo. 1052, 41080 Sevilla (Spain)
}

(Received May 9, 1989; accepted in revised form February 21, 1990)

\begin{abstract}
Lebrato, J., Pérez-Rodríguez, J.L., Maqueda, C. and Morillo, E., 1990. Cheese factory wastewater treatment by anaerobic semicontinuous digestion. Resour. Conserv. Recycl., 3: 193-199.

The processing of wastewater from a cheese factory in a semicontinuous anaerobic digester was studied. The experimental set-up consisted of six thermostatically-controlled digesters in a bath at $35 \pm 1{ }^{\circ} \mathrm{C}$, and magnetically stirred at $100 \mathrm{rpm}$. The best feeding for the culture medium was $0.633 \mathrm{~g}$ $1^{-1}$ day $^{-1}$. The minimum hydraulic retention time was nine days. The efficiency of treatment varied between 90 and $78 \%$. The composition of biogas was of high quality, with $67 \%$ of methane, and no trace of $\mathrm{H}_{2} \mathrm{~S}$.
\end{abstract}

\section{INTRODUCTION}

One of the most important motives for the development of wastewater treatment is to control the environmental problem. The wastewater of a cheese factory contains large amounts of dissolved whey, which cause problems in disposal as the cheese whey has a high chemical oxygen demand.

In the literature there are few data concerning the utilization of these wastewaters. De Haase and co-workers [1] used a downflow fixed-bed reactor, and they found it successful for the anaerobic digestion of diluted cheese whey. Recently, Lo and Liao [2] and Lo et al. [3] used a laboratory-scale anaerobic rotating biological reactor in the processing of a cheddar cheese whey. They concluded that two-state anaerobic fermentation was a suitable method for treating whey. Rouleau et al. [4] and Yan et al. [5 ] ] have also built two types of reactors in parallel, i.e., the downflow fixed film, and the upflow sludge blanket for these wastewater anaerobic treatment.

In the present study we have chosen the wastewater from a cheese factory in order to apply the anaerobic treatment method. This wastewater is easy to handle, does not contain large solid particles in suspension, and probable good 
digestibility, owing to the absence of polymers of difficult degradation. The subject of this study is as follows:

- physicochemical characterization of the wastewater;

- check of its digestibility and degree of its transformation into biogas;

- study of the treatment, quantity, and composition of gas and effluent produced in this process.

\section{MATERIALS AND METHODS}

Wastewater from a cheese factory was used. Samples were taken according to the standard methods [6], from a sewer that collected wastewater from all the factory processes. The wastewater was taken every six minutes over five hours in the central period of a working day (Wednesday). Seventy-five litres of sample were collected and, after characterization, were stored at $-20^{\circ} \mathrm{C}$.

\section{Experimental processes}

A battery of 6 anaerobic digestion reactors, each of one litre, was used. The digesters were inserted in a thermostatic water bath at $36 \pm 1{ }^{\circ} \mathrm{C}$ and were stirred by means of a magnetic stirring bar at $100 \mathrm{rpm}$. Figure 1 shows a diagram of the anaerobic digestion unit.

The digesters were inoculated with biomass from an anaerobic reactor that

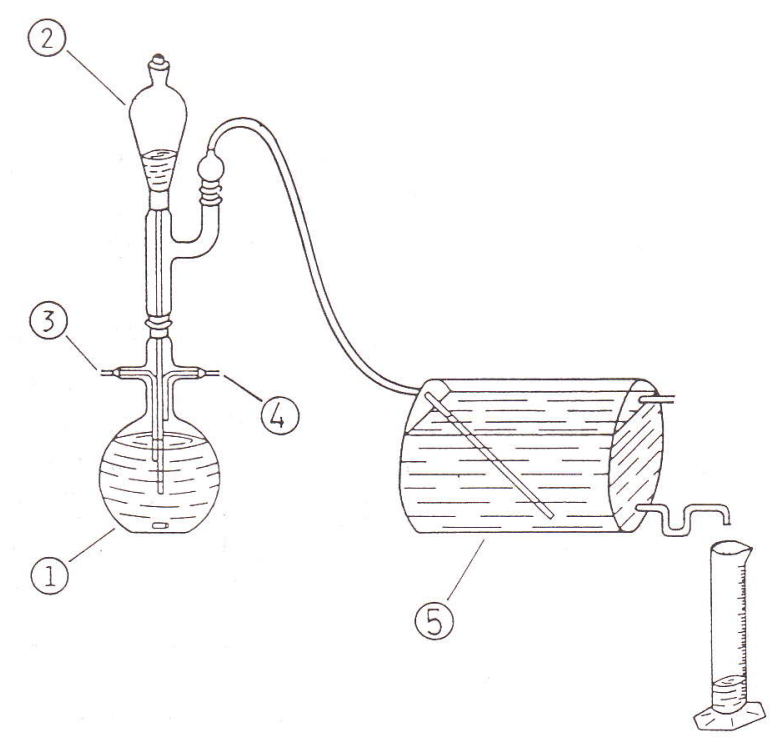

Fig. 1. Anaerobic digester reactor. 1: Digester, 2: feeding input, 3: effluent output, 4: $\mathrm{N}_{2}$ injection, 5: gasometer. 
processes piggery wastewater, which contained the methanogenic flora. On the eighth day there was started the change of feeding, adding wastewater from the cheese factory to the pig manure. The content of cheese wastewater was increased daily by $2 \%$; thus, after fifty days in the feeding liquid, only this wastewater was present. The sample of effluent was removed from the digester by over pressure of nitrogen injection. The feeding was performed from the top through a decantation funnel. The gas production was measured daily by the displacement of water in a Mariotte bottle.

Analyses

Before and after the process of digestion the following analyses of the wastewater by the standard methods for examination of water and wastewater [6] were carried out: density, viscosity, calorific capacity, content of total solids, mineral solids, volatile solids, conductivity, $\mathrm{pH}$, free ammonium, volatile acidity and chemical oxygen demand (COD).

Nitrogen and total phosphorus were determined by the Kjeldahl method, with the Nichols modification for digestion with hydrogen peroxide without a catalyst. Nitrogen was determined as free ammonium by a vapour stream and phosphorus by colorimetry of the phosphomolybdate formed.

Biogas composition was analysed with an Orsat apparatus, and $\mathrm{H}_{2} \mathrm{~S}$ with a multigas detector.

\section{RESULTS AND DISCUSSION}

According to data supplied by the factory, the wastewater contained $80 \%$ washing water and $20 \%$ whey, with a daily output of 500001 . The wastewater was analysed and results are shown in Table 1.

After the adaptation of the biomass to the wastewater from the cheese factory, it was fed at daily rate of $30 \mathrm{ml}$, until the biogas production in the digester was stabilised at about $300-320 \mathrm{ml} \mathrm{day}^{-1}$. The following step was to evaluate the optimum feeding amount, within a range of 30 to $50 \mathrm{ml}$, for water with about $17000 \mathrm{mg}^{-1} \mathrm{COD}[7]$.

Digesters 1 and 2 were fed at a constant feeding rate of $30 \mathrm{ml} \mathrm{day}{ }^{-1}$. In the other four digesters this was increased stepwise. The highest biogas production, $370 \mathrm{ml}$, corresponded to $37 \mathrm{ml} \mathrm{day}{ }^{-1}$, decreasing for higher feeding rates. This optimum amount of feeding $\left(37 \mathrm{ml} \mathrm{day}^{-1}\right)$ contained $633 \mathrm{mg}$ of organic matter, and corresponded to a hydraulic retention time (HRT) of 27 days.

The critical HRT was calculated by adding to the optimum feeding $(37 \mathrm{ml})$ increasing amounts of water, immediately after removing equal volumes of the effluent from the digester. One retention time was changed to another when the gas production stabilised.

The point at which the biogas production suddenly decreased was the crit- 
TABLE

Wastewater characterization from cheese factory

\begin{tabular}{lr}
\hline COD (ppm) & 17120 \\
Density $\left(\mathrm{kg} \mathrm{l}^{-1}\right)$ & 1.05 \\
Viscosity $\left(\mathrm{g} \mathrm{m}^{-1} \mathrm{~s}^{-1}\right)$ & 1.10 \\
Calorific capacity $\left(\mathrm{cal} \mathrm{g}^{-1}{ }^{\circ} \mathrm{C}^{-1}\right)$ & 0.9 \\
Total solids $(\mathrm{ppm})$ & 16800 \\
Mineral solids (ppm) & 6200 \\
Volatile solids (ppm) & 10600 \\
Total solids in suspension (ppm) & 6200 \\
Mineral solids in suspension (ppm) & 1000 \\
Volatile solids in suspension (ppm) & 5200 \\
Conductivity (mS) & 56.4 \\
pH & 4.1 \\
Free ammonium (ppm) & 50 \\
Volatile acidity (ppm) & 700
\end{tabular}

TABLE 2

Biogas production under standard conditions

\begin{tabular}{lrrrrrr}
\hline HRT (days) & 27 & 25 & 20 & 15 & 9 & 8 \\
Gas (ml) & 387 & 307 & 259 & 218 & 207 & 47 \\
\hline
\end{tabular}

ical HRT or "wash out" point, where the growing biomass is less than the biomass lost in the effluent daily.

The digesters operated with continuous stirring, and under these conditions the critical HRT was nine days, as shown in Table 2.

The gas production rate was within a range of $380-207 \mathrm{ml} \mathrm{day}^{-1}$. The feeding rate and effluent composition for each HRT are shown in Table 3. The gas yield was $0.11 \mathrm{~g}^{-1} \mathrm{COD} \mathrm{day}^{-1}$.

It can be seen that COD removal efficiency reaches values of between 78 and $90 \%$ for each HRT.

The self-regulation of $\mathrm{pH}$ at 7-7.4, optimal for this digestion process, for each HRT was observed due to formation of $\mathrm{CO}_{3} \mathrm{HNH}_{4}$ from $\mathrm{CO}_{2}$ and $\mathrm{NH}_{3}$ make-up in the process, which increases the alkalinity. Thus, any variation of volatile acids does not affect the $\mathrm{pH}$ (Table 4 ).

The biogas composition is shown in Table 5.

The composition of biogas is of a high quality, with $67 \%$ of methane, and no traces of $\mathrm{H}_{2} \mathrm{~S}$ were detected.

In order to compare the results obtained in this paper with the data from the bibliography, Table 6 shows the gas yields and hydraulic retention time (HRT) for different types of digesters and residues. Marshall and Timbers [8] and Switzenbaum and Dankin [9] obtained 0.27 and $0.23 \mathrm{~g} \mathrm{l}^{-1}$ COD 
TABLE 3

Feed $(F)$ and digested effluent $(E)$ composition $\left(\mathrm{mg}^{-1}\right)$ for various HRTs

\begin{tabular}{|c|c|c|c|c|c|c|c|c|c|c|c|c|c|c|}
\hline & \multicolumn{2}{|c|}{$\begin{array}{l}\text { HRT }=27 \\
\text { days }\end{array}$} & \multicolumn{2}{|c|}{$\begin{array}{l}\text { HRT }=25 \\
\text { days }\end{array}$} & \multicolumn{2}{|c|}{$\begin{array}{l}\text { HRT }=20 \\
\text { days }\end{array}$} & \multicolumn{2}{|c|}{$\begin{array}{l}\text { HRT }=15 \\
\text { days }\end{array}$} & \multicolumn{2}{|c|}{$\begin{array}{l}\text { HRT }=10 \\
\text { days }\end{array}$} & \multicolumn{2}{|c|}{$\begin{array}{l}\mathrm{HRT}=9 \\
\text { days }\end{array}$} & \multicolumn{2}{|c|}{$\begin{array}{l}\text { HRT }=8 \\
\text { days }\end{array}$} \\
\hline & $(F)$ & (E) & $(F)$ & (E) & $(F)$ & $(E)$ & $(F)$ & $(E)$ & $(F)$ & (E) & $(\mathrm{F})$ & $(\mathrm{E})$ & $(\mathrm{F})$ & $(\mathrm{E})$ \\
\hline TS & 16800 & 7100 & 15540 & 5100 & 12432 & 4700 & 9240 & 5500 & 6300 & 4010 & 6216 & 3600 & 4973 & 3000 \\
\hline MS & 6200 & 2900 & 5735 & 2000 & 4588 & 1900 & 3424 & 2400 & 2420 & 1580 & 2294 & 1500 & 1835 & 1200 \\
\hline VS & 10600 & 4200 & 9805 & 3100 & 7844 & 2800 & 5830 & 3100 & 3880 & 2430 & 3922 & 2100 & 3137 & 1800 \\
\hline TSS & 6200 & 2100 & 5735 & 1900 & 4588 & 1600 & 3410 & 1570 & 2600 & 1520 & 2294 & 1700 & 1835 & 1200 \\
\hline MSS & 1000 & 900 & 925 & 750 & 740 & 600 & 550 & 600 & 590 & 780 & 370 & 800 & 296 & 700 \\
\hline VSS & 5200 & 1200 & 4810 & 1150 & 3848 & 1000 & 2860 & 970 & 2010 & 740 & 1924 & 900 & 1539 & 500 \\
\hline $\mathrm{COD}$ & 17120 & 1600 & 15836 & 1500 & 12669 & 1400 & 9454 & 1400 & 7037 & 1548 & 6334 & 4450 & 5100 & 5100 \\
\hline \multirow{2}{*}{\multicolumn{15}{|c|}{$\begin{array}{c}\text { Depuration } \\
\text { efficiency } \\
(\%)\end{array}$}} \\
\hline & \multicolumn{2}{|c|}{90} & \multicolumn{2}{|c|}{90} & \multicolumn{2}{|c|}{89} & \multicolumn{2}{|c|}{85} & \multicolumn{2}{|c|}{78} & \multicolumn{2}{|c|}{29} & \multicolumn{2}{|c|}{0} \\
\hline
\end{tabular}

TS, total solids; MS, mineral solids; VS, volatile solids; TSS, total suspended solids; MSS, mineral suspended solids; VSS, volatile suspended solids; COD, Chemical oxygen demand.

TABLE 4

Values of $\mathrm{pH}$ and some related parameters for wastewater and effluents at various HRTs

\begin{tabular}{lccccccr}
\hline Parameter & Wastewater & \multicolumn{1}{l}{ Effluent } \\
\cline { 3 - 7 } & & HRT $=27$ & 25 & 20 & 15 & 10 & 8 days \\
\hline pH & 7.1 & 7.3 & 7.2 & 7.4 & 7.0 & 7.3 & 5.9 \\
$\begin{array}{c}\text { Conductivity } \\
(\mathrm{mS})\end{array}$ & & & & & & & \\
$\begin{array}{c}\text { Volatile acidity } \\
(\mathrm{ppm})\end{array}$ & 56.4 & 86.5 & 81.0 & 78.0 & 79.0 & 76.9 & 84.0 \\
$\begin{array}{c}\text { Free } \\
\text { ammonium } \\
(\text { ppm })\end{array}$ & 716.0 & 370.0 & 530.0 & 800.0 & 800.0 & 900.0 & 1500.0 \\
$\begin{array}{c}\text { Alkalinity } \\
(\mathrm{ppm})\end{array}$ & - & 530.0 & 500.0 & 500.0 & 470.0 & 460.0 & 460.0 \\
\hline
\end{tabular}

respectively, less than the 0.35 of the theoretical study of McCarty [10]. These values are greater than those obtained in this paper $(0.11)$. The better gas yields from these authors are possibly due to their using whey from a cheese factory, instead of wastewater, which is less concentrated, and less suitable for the anaerobic digestion.

Lo and Liao [2], in the treatment of whey, obtained good results using two stages, fermentative and methanogenic.

The lower results obtained in this paper can be also attributed to the type of digester causing daily loss of biomass in the effluent. 
TABLE 5

Biogas composition (\%)

$\begin{array}{lr}\mathrm{CH}_{4} & 67 \\ \mathrm{H}_{2} & 5 \\ \mathrm{CO}_{2} & 22 \\ \mathrm{O}_{2} & 1 \\ \mathrm{~N}_{2} & 5 \\ & 100\end{array}$

TABLE 6

Gas yields and hydraulic retention times for different types of digesters and residues

\begin{tabular}{|c|c|c|c|c|}
\hline Waste & Digester type & $\begin{array}{l}\text { Hydraulic } \\
\text { retention time }\end{array}$ & $\begin{array}{l}\text { Gas yields } \\
\left(\mathrm{g} \mathrm{l}^{-1} \mathrm{COD} \mathrm{day}^{-1}\right)\end{array}$ & Reference \\
\hline $\begin{array}{l}\text { Theoretical } \\
\text { study }\end{array}$ & - & - & 0.35 & McCarty [10] \\
\hline $\begin{array}{c}\text { Domestic } \\
\text { sewage }\end{array}$ & $\begin{array}{l}\text { Semicontinuous } \\
\text { stirring }\end{array}$ & 6 days & 0.19 & Lebrato [11] \\
\hline Whey & Fixed film & 5 days & 0.27 & $\begin{array}{l}\text { Marshall and } \\
\text { Timbers [8] }\end{array}$ \\
\hline Whey & $\begin{array}{l}\text { ANRBC, two } \\
\text { stage }\end{array}$ & 5 days & 0.42 & Lo and Liao [2] \\
\hline Whey & Expanded bed & 9 hours & 0.23 & $\begin{array}{c}\text { Switzenbaum and } \\
\text { Danskin [9] }\end{array}$ \\
\hline $\begin{array}{c}\text { Cheese factor } \\
\text { wastewater }\end{array}$ & $\begin{array}{l}\text { Semicontinuous } \\
\text { stirring }\end{array}$ & 8 days & 0.11 & This study \\
\hline $\begin{array}{l}\text { Domestic } \\
\text { sewage }\end{array}$ & $\begin{array}{l}\text { Rotatory fixed } \\
\text { film }\end{array}$ & - & 0.11 & $\begin{array}{l}\text { Noyola et al. } \\
{[12]}\end{array}$ \\
\hline
\end{tabular}

The digesters with fixed or expanded bed have higher process speeds, so the HRTs are lower than for the shaken reactors.

\section{CONCLUSIONS}

(1) This type of waste from a cheese factory is digestible and it has good conditions for fluid transport in a plant, because it has no large particles in suspension. This makes its pretreatment unnecessary.

(2) The minimum HRT is nine days.

(3) The biogas composition is of high quality with $67 \%$ of methane, and no trace of $\mathrm{H}_{2} \mathrm{~S}$.

(4) The efficiency in depuration is high, $78 \%$ for a minimum HRT, reaching $90 \%$ for higher HRTs. 


\section{REFERENCES}

1 De Haast, J., Britz, T.J., Novello, J.C. and Lategau, P.M., 1983. Anaerobic digestion of cheese whey using a stationary fixed bed reactor. N.Z. J. Dairy Sci. Technol., 18: 261-271.

2 Lo, K.V. and Liao, P.H., 1986. Digestion of cheese whey with anaerobic rotating biological contact reactors. Biomass, 10: 243-252.

3 Lo, K.V., Liao, P.H. and Chiu, C., 1988. Mesophilic anaerobic digestion of a mixture of cheese whey and dairy manure. Biomass, 15: 45-53.

4 Rouleau, G., Marcil, G. and Peters, R., 1983. Sci. Techn. de l'Eau, 4: 371-376.

5 Yan, J.Q., Lo, K.V. and Liao, P.H., 1989. Biol. Wastes, 27: 289-305.

6 Franson, M.A. (Editor), 1975. Standard Methods for the Examination of Water and Wastewater. APHA, Washington, DC, 14th ed.

7 O'Rourke, J.R., 1968. Kinetics of anaerobic treatment at reduced temperatures. Ph.D. Thesis, Stanford University, Stanford, CA.

8 Marshall, D. and Timbers, G.E., 1982. Development and testing of a prototype fixed film anaerobic digester. Winter Meeting ASAE, St. Joseph, Michigan. 82: 6519.

9 Switzenbaum, M.S. and Danskin, S.C., 1982. Anaerobic expanded bed treatment of whey. Agric. Waste, 4: 411-426.

10 McCarty, P.L., 1964. Anaerobic waste treatment fundamentals. Publ. Works, 95: 9-11.

11 Lebrato, J., 1990. Obtención de biogas a partir de residuos orgánicos domésticos: Experiencias en lecho fluidizado. Thesis, University of Sevilla.

12 Noyola, A., Capdeville, B. and Roques, H., 1988. Anaerobic treatment of domestic sewage with a rotating stationary fixed film reactor. Water Res., 22(12): 1585-1592. 